practice in Melbourne Hospital in those pre-antiseptic days. He proceeded to London in 1883, obtained the fellowship of the Royal College of Surgeons, London, became demonstrator of physiology in King's College, London, under Gerald Yeo, and commenced his career as an ophthalmic surgeon as assistant at Moorfields Eye Hospital. Interesting recollections are given of Bowman, McCarthy and Michael Foster, Gaskell and Langley, and Jonathan Hutchinson and Whittaker Hulke, all well-known figures in the medical world of the time; he also visited the Continent, and met Koch in Berlin. Then come recollections of the Great War, and the organization of the medical service in Egypt. The organization of "bush nursing centres" in Australia is recounted, a scheme initiated in 1908 by the Countess of Dudley, and finally, Sir James has a good deal to say upon education and university extension, and recalls some of his meetings with British statesmen.

\section{The British Medical Association: Plymouth Meeting}

Dr. Colin LINDSAY presided at the one hundred and sixth annual meeting of the British Medical Association, held at Plymouth on July 19 and following days. "The Profession and the Public" was the title of the address of Dr. Lindsay, who pointed out that his remarks were based upon an experience of forty years as general practitioner and consulting physician. He emphasized the need for continued education both for the public and for the practitioner, and the necessity that exists for a specialist service to supplement the service of the family doctor, for medicine has grown so enormously that it is quite impossible for any one person to be proficient in every branch. He reminded the public of the unity and equality of the three main branches of the profession-the general practitioners, the consultants and the members of the public health service-which are essentially complementary, each requiring for its proper performance attainments of the highest order. He desires to see more attention paid to the treatment of the so-called 'minor ailments', for it has been estimated that forty per cent of all sickness is due to the patient's own action. The principle of 'free choice of doctor' under National Health Insurance was stressed, and the Association's proposals for a general medical service for the nation were outlined, by which members of families within an income limit of $£ 250$ a year would be included. Other topics dealt with were the fees to be paid for consultative work, the education of the public in the use of the doctor, and the countering of credulity on the part of the public.

\section{Lister Institute of Preventive Medicine}

THE report of the Governing Body of the Lister Institute of Preventive Medicine, presented at the annual general meeting on June 2, gives an account of the researches carried out at the Institute during the past year. Several studies on viruses, vaccinia and others, are detailed, with an investigation on the problem of rheumatic diseases, in which viruslike bodies occur. Dr. Felix and others have con- tinued their work on the antigenic constitution, virulence and immunizing properties of bacteria and Protozoa, and the chemistry of bacterial antigens has also been investigated. The Svedberg velocity ultracentrifuge, installed some time ago, has given satisfactory service, and several proteins have been the subject of study with this instrument. Many studies on vitamins, their chemistry and action have been prosecuted by Dr. Harriette Chick and her co-workers. The Institute is the home of the National Collection of Type Cultures, and more than 6,000 cultures have been distributed to workers at home and abroad. Sir John Ledingham, the director, his staff and attached workers may be congratulated on their fine output of work.

\section{Medical Classics}

Two important medical classics which were recently published in the Bulletin of the Institute of the History of Medicine have just been reprinted in book form and thereby made accessible to a wide circle of readers. The first of these, entitled "On Thought in Medicine", is the address delivered by Hermann von Helmholtz on August 2, 1877, on the anniversary of the foundation of the Institute for the Education of Army Surgeons. In this address, Helmholtz attacks the old educational system which he regards as pursuing a false idea of science, in which there is a one-sided and erroneous reverence for the deductive method. Medical education during the early part of the nineteenth century in Germany was based mainly on the study of books. There were no physiological or physical laboratories, and microscopical demonstrations were infrequent in lectures. It fell to Johannes Müller and his pupils, of whom Helmholtz was one, to stimulate the study of microscopical and pathological anatomy, experimental pathology and therapeutics and to substitute experimental research for untried and unconfirmed hypotheses.

THE second volume contains a translation of Ivan Sandström's work entitled "On a New Gland in Man and Several Animals (Glandulæ Parathyroideæ)", which was published in vol. 15 of the Swedish journal Upsala Läkareförenings Förhandlinger for 1879-80, and represents the first detailed description of the parathyroid glands, based on the naked-eye and microscopical examination of these glands in the dog, cat, rabbit, ox and about fifty human subjects. It is noteworthy that whereas the translation of Helm. holtz's address was published so long ago as 1893, the English version of Sandström's monograph now appears for the first time, and has been carried out by Dr. Carl Seipel, who has also translated an account of Sandström's life and work by Prof. A. J. Hamman of Stockholm.

\section{Jubilee of the Gypsy Lore Society}

THrs year the Gypsy Lore Society celebrates the fiftieth year of its existence. The occasion was marked by a jubilee dinner on June 11, over which Lady Arthur Grosvenor (president, 1913-14) pre- 
sided in the unavoidable absence of the president, Mr. Augustus John, and at which fifty-five members and guests were present. The Gypsy Lore Society was founded in 1888 by Charles Godfey Leland ("Hans Breitmann") and David MacRitchie of Edinburgh. Leland's enthusiasm for gypsy studies, characteristically overpowering, dated from 1870 , when he settled in England for a period of years. Although he wrote several books on the gypsies between 1873 and 1882 , it was not until 1888, three years after his return to England, that his desire to promote a wider interest in the investigation of the gypsy problem took practical shape in the foundation of a society devoted to that object; and indeed its formation was owing largely to his association with the organizing ability and scholarly habit of mind of MacRitchie, to whom also was due, with John Sampson and R. A. S. Macfie, the resuscitation of the Society in 1907, when it had been dormant for a period of years through lack of funds. Among the eleven original members, who formed the nucleus of the Society, were H. T. Crofton, Elizabeth Robbins Pennell, Leland's niece, famous as an interpreter of Ibsen's heroines on the stage, the Archduke Joseph of Austria, a fluent Romani linguist, Sir Richard Burton, the famous, if difficult, orientalist and traveller, Paul Bataillard, F. H. Groome, most eminent of the early students of gypsy folk-lore, and Walter Herries Pollock; while one of the earliest adherents in the United States was Mary Alicia Owen, later known as an authority on the folk-lore of the American Indian, whose early studies of the traditional tales and beliefs of the negroes of Missouri, if modelled on the "Uncle Remus" of Georgia of Joel Chandler Harris, were directly inspired by Leland's encouragement.

IN an introductory article which opens a special jubilee number of the Journal of the Gypsy Lore Society, the editor, Archdeacon F. G. Ackerley, enumerates some of the more noteworthy contributions to the investigation of the gypsy problem which have appeared in its pages and elsewhere since the foundation of the Society. Among contributors to the Journal, the late Dr. John Sampson naturally takes a high place, not only on account of his linguistic studies, but also for his collection of Welsh Romani folk-tales; but it will be generally agreed that the term 'epoch-marking' here applied to Prof. R. A. S. Macalister's collection of material bearing on the language of the Nawar of Palestine is appropriate in more than a conventional and complimentary sense. It gave a new orientation to the study of the gypsy problem. Outside its own publications, the influence of the Society is to be seen in Dr. John Sampson's "Dialect of the Gypsies of Wales" (1926), which has been termed "the best of all Gypsy linguistic studies in any language" and Prof. E. Pittard's "Les Tsiganes ou Bohémiens" (1932) in which "is presented once and for all the physical anthropology of the race". Two great services the Society has performed for gypsy studies: it has abolished the pseudo-romantic rubbish which formerly passed for gypsy-lore, and it has exploded the popular association of gypsies with Egypt by laying down the true lines for the investigation of the problem of their origin. It is difficult to say which has been the greater service to learning.

\section{Archæological Collections in Spain}

NotwithstANDING reports of damage sustained by archæological collections in the museums of Madrid, it is now announced that an official verification by the Ministry of Public Instruction and the Municipality of Madrid has established the fact that the collections of both the Archæological Museum and the Anthropological Museum of Madrid are intact. Prof. Bosch Gimpera, to whom the editors of $L$ 'Anthropologie $(48,3-4 ; 1938)$ are indebted for the information, goes on to add that the other museums of the area under the Republican Government have been preserved from damage, while the official departments responsible for antiquities are taking every necessary precaution for their safety. As regards the museum at Valencia and the Catalan museums, Prof. Bosch Gimpera, as head of the antiquities service, is able to give his own personal assurance of their safety to his archæological colleagues outside Spain.

\section{Italian Anthropological Expedition to Erythraea}

ON his return at the close of last year from an expedition to the Tana basin of Ethiopia, Prof. I. Cipriani, director of the Anthropological I Laboratory of the University of Florence, was forthwith placed in charge of an anthropological mission to northern Erythraea for the purpose of studying the littleknown peoples north of Cheren. This mission was under the joint auspices of the Royal Academy of Italy and the Bureau of Colonial Studies of Florence. The expedition lasted from December 1937 until March 1938. According to a preliminary note of the results (L'Anthropologie, 48, 3-4; 1938), anthropometric measurements were made of 450 subjects, of whom there were 70 Bogo, 94 Mària, 26 Habab, and 159 representatives of groups adjacent to the last-named. For purposes of comparison, measurements were also made of 29 Abyssinians, as well as 30 Baria women and 20 Rasciàida. The blood groups were tested in 110 subjects. A further result of the expedition was the discovery of a large number of rock paintings in the granite caves of Carora near the Anglo-Egyptian frontier, as well as of stone implements of palæolithic type, the first to be recorded in Erythraea. Finally the expedition brought back to Italy 68 masks taken from the living, and more than two thousand photographs of ethnographical and anthropological subjects.

\section{Stone Age Village in Yorkshire}

Now that archæological research aims at the reconstruction of a cultural phase as a whole, rather than at bringing to light by excavation individual antiquities of exceptional interest or artistic merit, the announcement of the discovery of a remote but complete village of the stone age at Rinyo on the Island of Rousay, Orkney (The Times, July 29) has an importance which transcends the intrinsic interest of any individual object likely to be obtained there. 